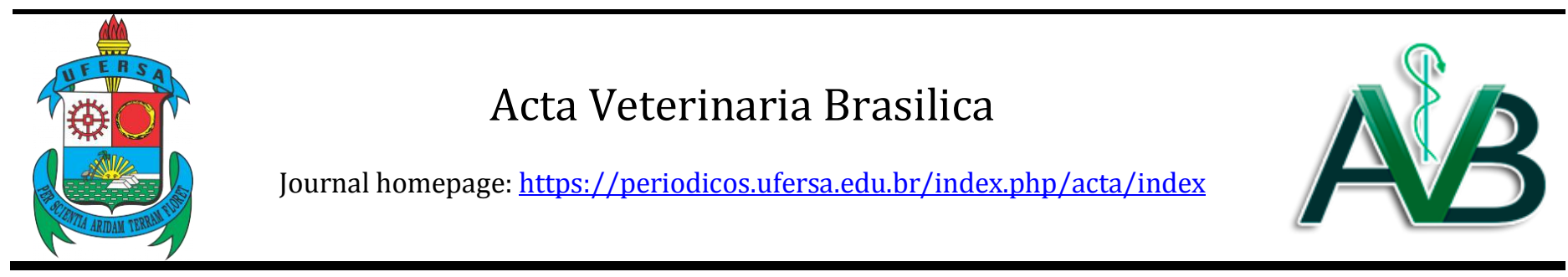

Clinical Reports

\title{
Metastatic T-cell lymphoma of unknown primary origin in a dog (Canis lupus familiaris)
}

Ramon Tadeu Galvão Alves Rodrigues ${ }^{1}$, Ismael Lira Borges ${ }^{1}$, Telma de Sousa Lima², Mayara Leal Firmino da Silva ${ }^{3}$, Poliana Araújo Ximenes ${ }^{4}$, José Artur Brilhante Bezerra ${ }^{5}$, Kilder Dantas Filgueira ${ }^{5 *}$

1 Universidade Federal de Campina Grande (UFCG), Patos, Paraíba, Brazil.

2 Universidade Federal da Paraíba (UFPB), Areia, Paraíba, Brazil.

${ }^{3}$ Autonomous veterinary, João Pessoa, Paraíba, Brazil.

${ }^{4}$ Autonomous veterinary, Fortaleza, Ceará, Brazil.

5 Universidade Federal Rural do Semi-Árido (UFERSA), Mossoró, Rio Grande do Norte, Brazil.

\section{A R T I C L E I N F O}

\begin{tabular}{l} 
Article history \\
Received 22 February 2017 \\
Received in revised form 03 August 2017 \\
Accepted 09 August 2017 \\
\hline
\end{tabular}

Keywords:

Hematopoietic neoplasm

Metastasis

Anti-CD3 antibody

Canine

\section{INTRODUCTION}

Canine lymphoma is a hematopoietic neoplasm, characterized by the clonal proliferation of malignant lymphocytes, originating mainly in lymphoid organs, although different tissues of the organism may be affected (RODRIGUES et al., 2016; ZANDVLIET, 2016). Several classification methods are proposed for lymphoma according to neoplastic cell morphology,

\begin{abstract}
A B S T R A C T
Canine lymphoma is a hematopoietic neoplasm that can affect different tissues. Its classification is performed according to cellular morphology, clinical stage, immunophenotyping, and anatomical location. However, in some cases, an oncopathy might be in an advanced stage with a plain organic spread, making it impossible to determine the initially affected tissue, which is a rare situation in animals. Thus, a case of metastatic lymphoma, of unknown primary origin, was described in a four-year-old Rottweiler bitch with multiple nodular subcutaneous proliferations. Hematological, biochemical, thoracic radiography, and abdominal ultrasound tests were performed, as well as a cytopathological examination of subcutaneous lesions and bone marrow. Hematologic findings determined anemia, lymphopenia, and thrombocytopenia. The thoracic radiography revealed multiple nodular masses. Cytopathological examination revealed infiltration of malignant lymphocytes into the subcutaneous nodules and into the bone marrow. The dog was euthanized and submitted to necroscopic examination, in which multiple nodules were found in the subcutaneous region, lung, pericardium, gastrointestinal tract and in the skeletal musculature, in addition to lymphadenopathy. Fragments of the affected structures were collected for later histopathological and immunohistochemical evaluation. Histopathological examination revealed the presence of neoplastic cells compatible with diffuse lymphoma, which was positively immunolabelled for T-cell lymphoma. Based on clinical-pathological findings and other complementary tests, a diagnosis of diffuse T-cell lymphoma of unknown primary origin was made. In order to classify hematopoietic neoplasms, it is essential to perform different laboratory tests. However, determination of origin becomes difficult when such an oncological disease presents an advanced stage.
\end{abstract}

primary anatomical location, clinical stage, and immunophenotyping (MARCONATO; GELAIN; COMAZZI, 2012). Considering the anatomical classification, the following lymphomas can be observed: multicentric lymphoma with generalized lymphadenopathy; mediastinal lymphoma, in which the thymus and/or mediastinal lymph nodes are affected; alimentary or gastrointestinal lymphoma; cutaneous lymphoma; and extranodal lymphoma, where non-lymphoid organs such

\footnotetext{
* Corresponding author: kilder@ufersa.edu.br
} 
as the brain, kidney, and eyeball are primarily affected (RODRIGUES et al., 2016).

The primary anatomical identification of the lymphoma is obtained through the association of clinical signs with the findings of the cytological and/or histopathological examination of the compromised tissue (ZANDVLIET, 2016). In addition, other laboratory tests, such as blood count, serum biochemistry, and imaging tests are of fundamental importance in determining the extent of neoplastic malignancy and defining clinical staging (MARCONATO; GELAIN; COMAZZI, 2012). However, for some neoplasms, determining the tissue initially affected is not possible (ROSSI et al., 2015; ZANDLIET, 2016).

Neoplasms of unknown primary origin, commonly referred to as cancer of unknown primary origin (CUP), are characterized by the presence of metastatic disease. However, the physical and complementary exams do not allow the localization or determination of the primary neoplasm, implying limitations to the definitive diagnosis and to the institution of an adequate treatment, besides being associated with a poor prognosis (SONDERGAARD et al., 2017). In dogs, reports addressing CUP are still scarce, and the main neoplasms involved in these processes are carcinomas and sarcomas (ROSSI et al., 2015).

Lymphomas are not classified as CUP since the identification of the primary neoplasm is easily determined in most cases (ROSSI et al., 2015). However, in dogs with advanced and rapidly evolving metastatic lymphoma, the anatomic classification of this neoplasm may not be possible, implying difficulty in the precise diagnosis and therapeutic planning (SILVA; SEQUEIRA, 2016). Thus, the present report aimed to describe a case of diffuse lymphoma, at stage $\mathrm{V}$ and of rapid evolution; however, its primary location could not be identified in a four-year-old female-dog with multiple subcutaneous nodular proliferations.

\section{CASE REPORT}

A four-year-old female Rottweiler, weighing $34 \mathrm{~kg}$, was treated at the Veterinary Hospital of the Rural Federal University of the Semi-Arid (UFERSA, Mossoró, Rio Grande do Norte, Brazil), with a history of anorexia, cough, breathing-pattern changes, and fast-growth oneweek skin neoplasms.

The animal underwent a physical examination, and multifocal neoplasms were present in the subcutaneous tissue. These neoplasms ranged from 1.0 to $3.0 \mathrm{~cm}$ in diameter, presented firm consistency, being adhered and distributed throughout the thoracic (dorsal and ventral), ventral abdominal regions, and medial aspect of the thoracic limbs (Figure 1). Moreover, asthenia, right lateral decubitus attitude, generalized superficial lymphadenopathy, edema in all limbs, the presence of pain during palpation, and mixed dyspnea were observed.

Figure 1 - A: Multifocal subcutaneous neoplasm in the ventral thoracic and abdominal ventral regions in a dog with metastatic lymphoma (yellow arrows). B: Subcutaneous neoplasm, adjacent to the left inguinal mammary gland. C: Same neoplasm of image B without manual delimitation (yellow arrow).

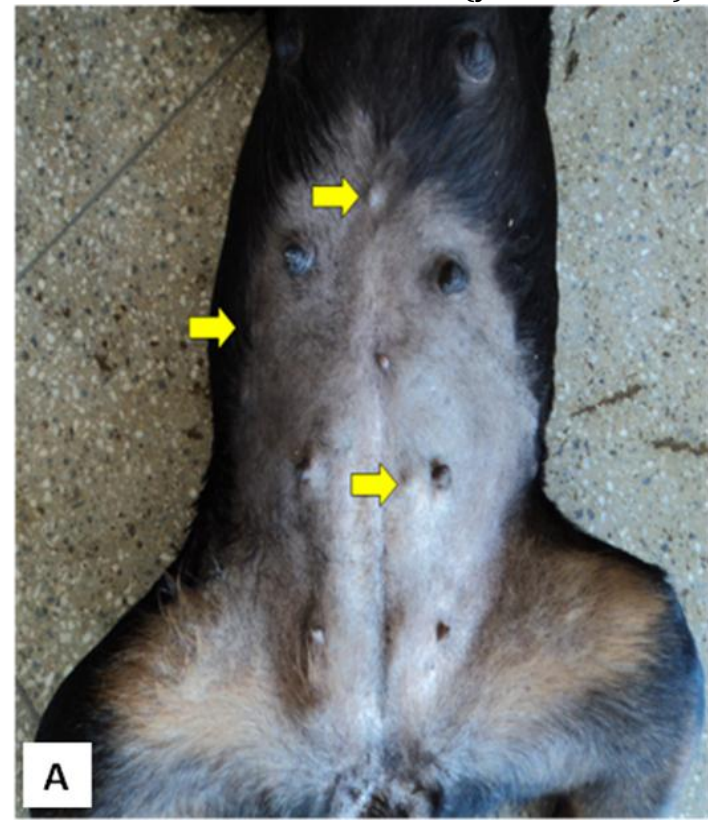

Source: Personal archive.

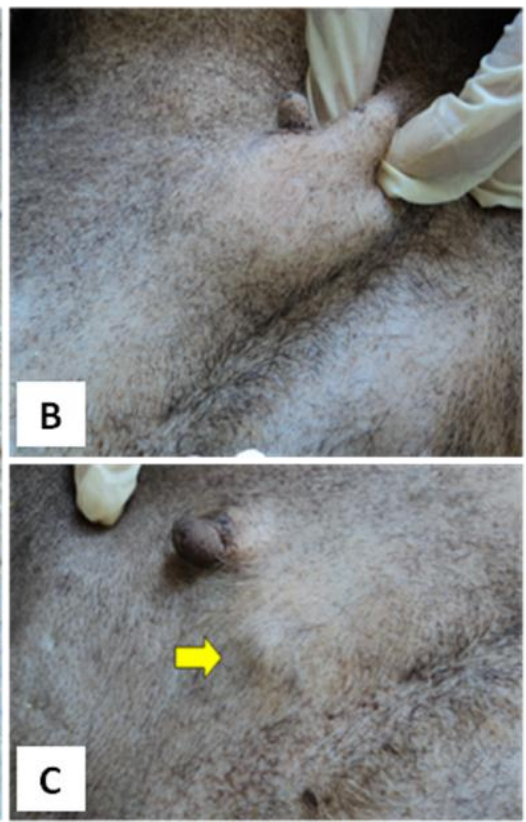

Hemogram, serum biochemical profile (creatinine, alanine aminotransferase, alkaline phosphatase and ionic calcium), cytological exams of the subcutaneous neoplasms and bone marrow, thoracic radiography and 
abdominal ultrasonography were performed. The hemogram showed the presence of normocyticnormochromic anemia, lymphopenia, and thrombocytopenia. Biochemical tests showed values within the reference range for the species, except for mild hypocalcemia (Table 1).

Table 1. Results of hematological and biochemical tests of the animal affected by a lymphoid neoplasm of unknown origin.

\begin{tabular}{lcc}
\hline Parameter & Value found & Reference range * \\
\hline Hematology & & 5.5 to $8.5 \mathrm{million}^{*} \mathrm{~mm}^{3}$ \\
\hline Red Blood Cells & 3.8 & 12 to $18 \mathrm{~g} / \mathrm{dL}$ \\
Hemoglobin & 9,35 & 37 to $55 \%$ \\
Hematocrit & 29 & 60 to $77 \mathrm{u}^{3}$ \\
MCV & 76 & 31 to $34 \%$ \\
MCHC & 32 & 6 to 17 thousand $/ \mathrm{mm}^{3}$ \\
Total leukocytes & 6,600 & 3,600 to $13,800 / \mathrm{mm}^{3}$ \\
Segmented neutrophils & 5,544 & 120 to $1,800 / \mathrm{mm}^{3}$ \\
Eosinophils & 198 & 720 to $5,400 / \mathrm{mm}^{3}$ \\
Lymphocytes & 594 & 200 to 500 thousand/mm \\
Platelets & 150 thousand & \\
\hline Serum biochemistry & & 0.5 to $1.5 \mathrm{mg} / \mathrm{dL}$ \\
\hline Creatinine & 0.7 & 0 to $110 \mathrm{u} / \mathrm{L}$ \\
Alanine aminotransferase & 62 & 20 to $160 \mathrm{u} / \mathrm{L}$ \\
Alkaline phosphatase & 13 & 9 to $11.3 \mathrm{mg} / \mathrm{dL}$ \\
Ionic calcium & 7.8 & .
\end{tabular}

MCV: Mean corpuscular volume; MCHC: Mean corpuscular hemoglobin concentration. *Source: Tesser et al. (2016) and Costa et al. (2015).

The cytopathological examination of cutaneous lesions and bone marrow showed infiltration of individualized malignant lymphoid cells with round nuclei, sometimes presenting indents, being discreetly pleomorphic, exhibiting coarse chromatin and poorly evident nucleoli.
The cytoplasm was sparse, basophilic, and had vacuoles. Anisocytosis and anisokaryosis were present. The cytologic picture was compatible with lymphoma (Figure 2).

Figure 2 - Photomicrography of cytologic examination of canine lymphoma of unknown primary site.

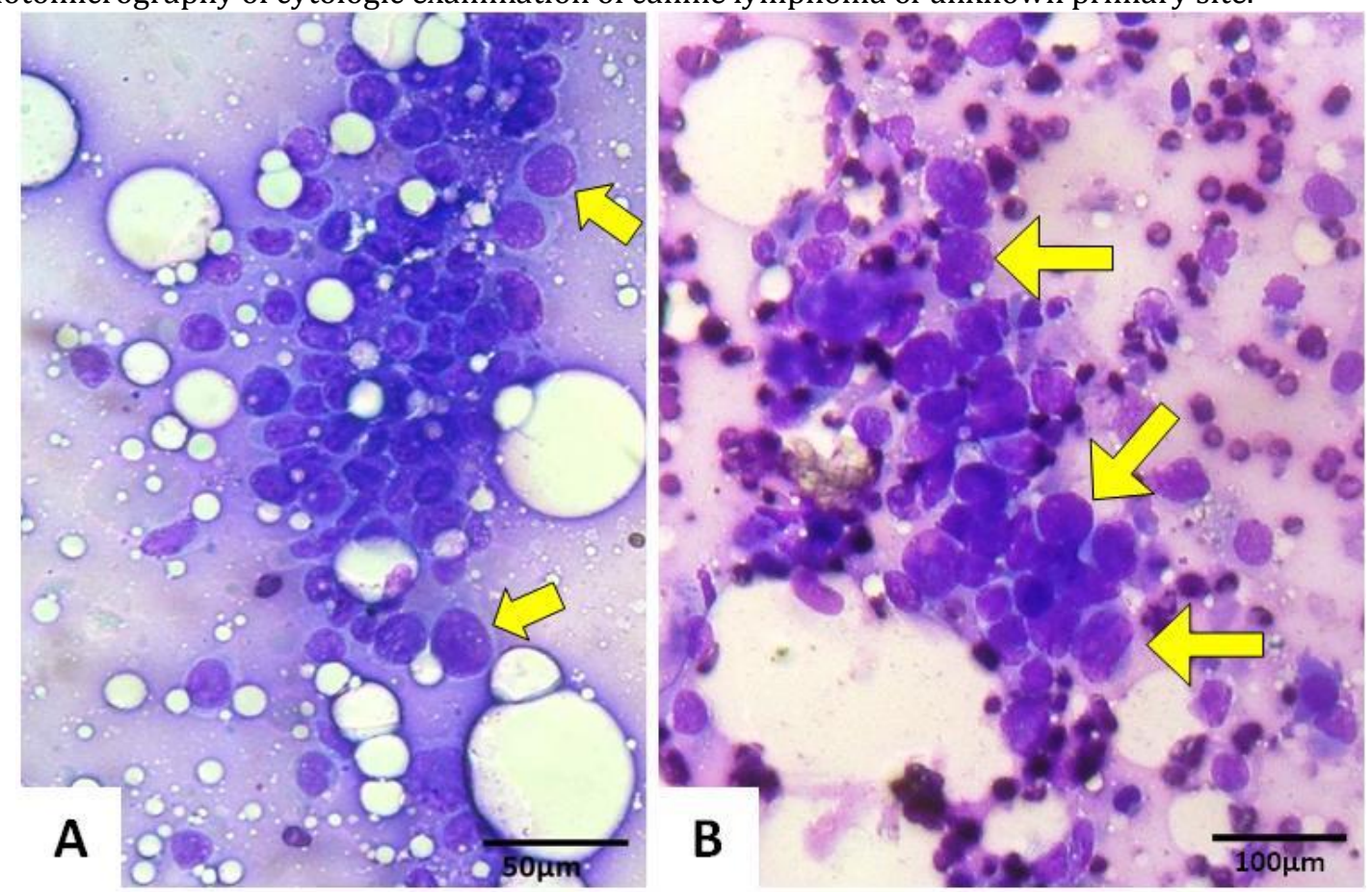

A: Subcutaneous proliferation exhibiting neoplastic lymphocytes (yellow arrows), with anisocytosis, anisokaryosis, and nucleoli sometimes difficult to distinguish, the cytoplasm is sparse and basophilic (40x objective, rapid Romanowsky stain). B: Bone marrow evidencing neoplastic lymphoid cell infiltrate (yellow arrows) (20x objective, rapid Romanowsky stain). Source: Personal archive. 
Thoracic radiography revealed the presence of radiopaque nodular masses in the pulmonary parenchyma, suggestive of neoplastic processes (Figure
3), whereas abdominal ultrasonography showed no structural alteration of the cavity organs.

Figure 3 - Thoracic radiography of a bitch affected by metastatic lymphoma of unknown primary site, showing a nodular pulmonary pattern (yellow arrow) of high radiopacity, in a latero-lateral projection.

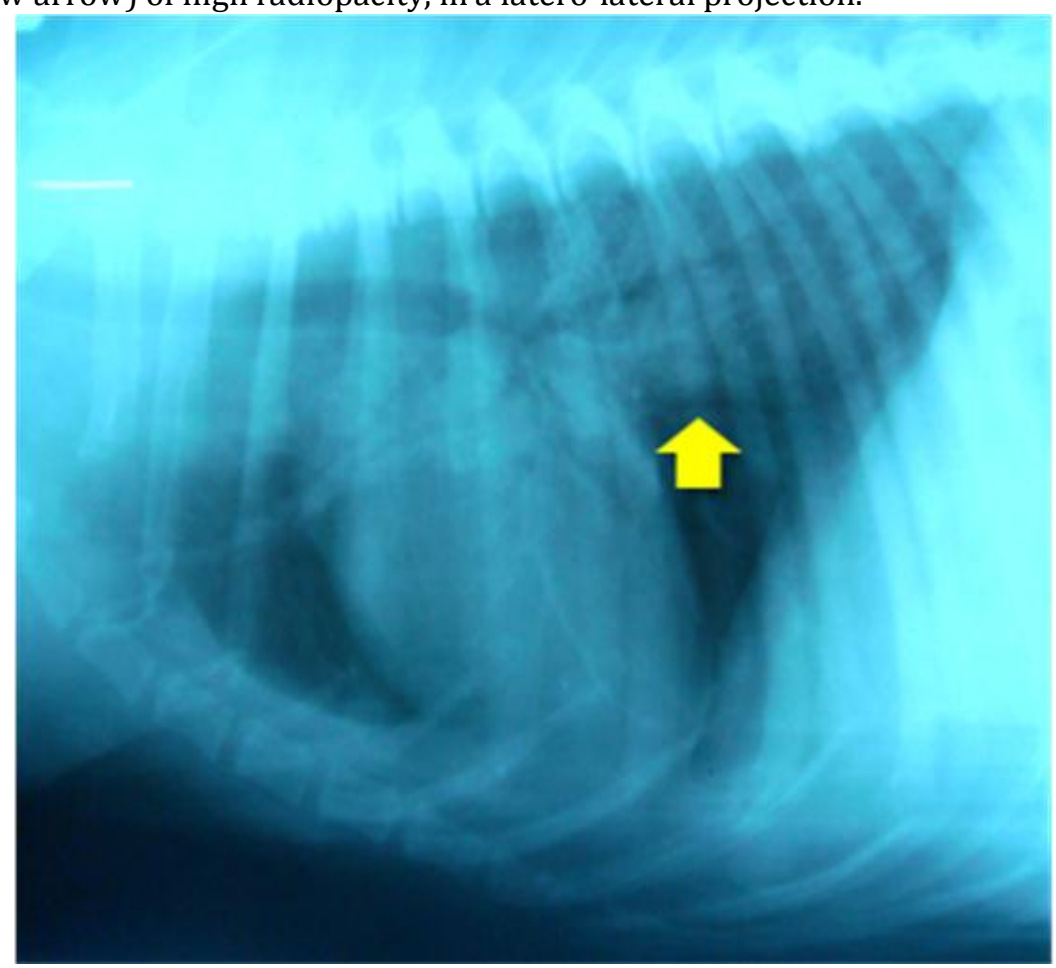

Source: Personal archive.

The presence of neoplastic lymphocytes in the bone marrow led to the establishment of V-stage, which has the longest duration and the highest severity for lymphoma. Due to the high degree of weakness of the animal, in association with the laboratory results and clinical stage of the neoplasm, the tutor opted for euthanasia. The dog was referred for necropsy.

The necroscopic examination showed pale ocular and oral mucous membranes, subcutaneous edema in all limbs, but more pronounced in the pelvic limbs, and multiple subcutaneous and intermuscular neoplasms along the trunk and limbs, in musculature adjacent to the skull and diaphragm, with a diameter ranging from 1.0 to $3.0 \mathrm{~cm}$. The superficial lymph nodes were enlarged, with architecture subverted and loss of the corticomedullary ratio. The left popliteal lymph node exhibited a narrow, circumscribed white nodular focal area measuring 1.0 $\mathrm{cm}$ in diameter. Lung and adipose tissue surrounding the pericardium showed multifocal nodules with coalescences of 1.0 to $3.0 \mathrm{~cm}$ in diameter. In the esophagus, stomach (region of the gastric fundus) and large intestine, multifocal nodules were observed, with central areas depressed and varying from 1.0 to $3.0 \mathrm{~cm}$ in diameter. All nodules described were firm and presented a white and compact cut surface (Figure 4). In addition, the liver showed evidence of a lobular pattern, and the spleen showed a moderate extent of siderocalcinosis plaques, mainly at the borders.

Samples were collected from the affected structures and sent for histopathological examination, being then stained with hematoxylin and eosin. Microscopically, a neoplastic proliferation was observed and characterized by the presence of coalescing foci of round cells, which are characteristic of small and medium lymphocytes with evident nucleoli, randomly distributed in the nucleus. They presented marked anisocytosis and cellular atypia, and high mitotic index. Histopathological findings were consistent with diffuse lymphoma of intermediate cells (Figure 5). According to the clinicalpathological findings, a metastatic lymphoma was diagnosed, though it was not possible to determine the location of the primary neoplasm.

With the purpose of assigning the immunophenotypic characteristics of the neoplasm, an immunohistochemical examination was performed to search for molecular markers expressed on $\mathrm{T}$ lymphocytes and B lymphocytes, concluding the existence of a T-cell lymphoma (Figure 5 and Table 2). 
Figure 4 - Necropsy findings of the animal with unknown primary site lymphoma.
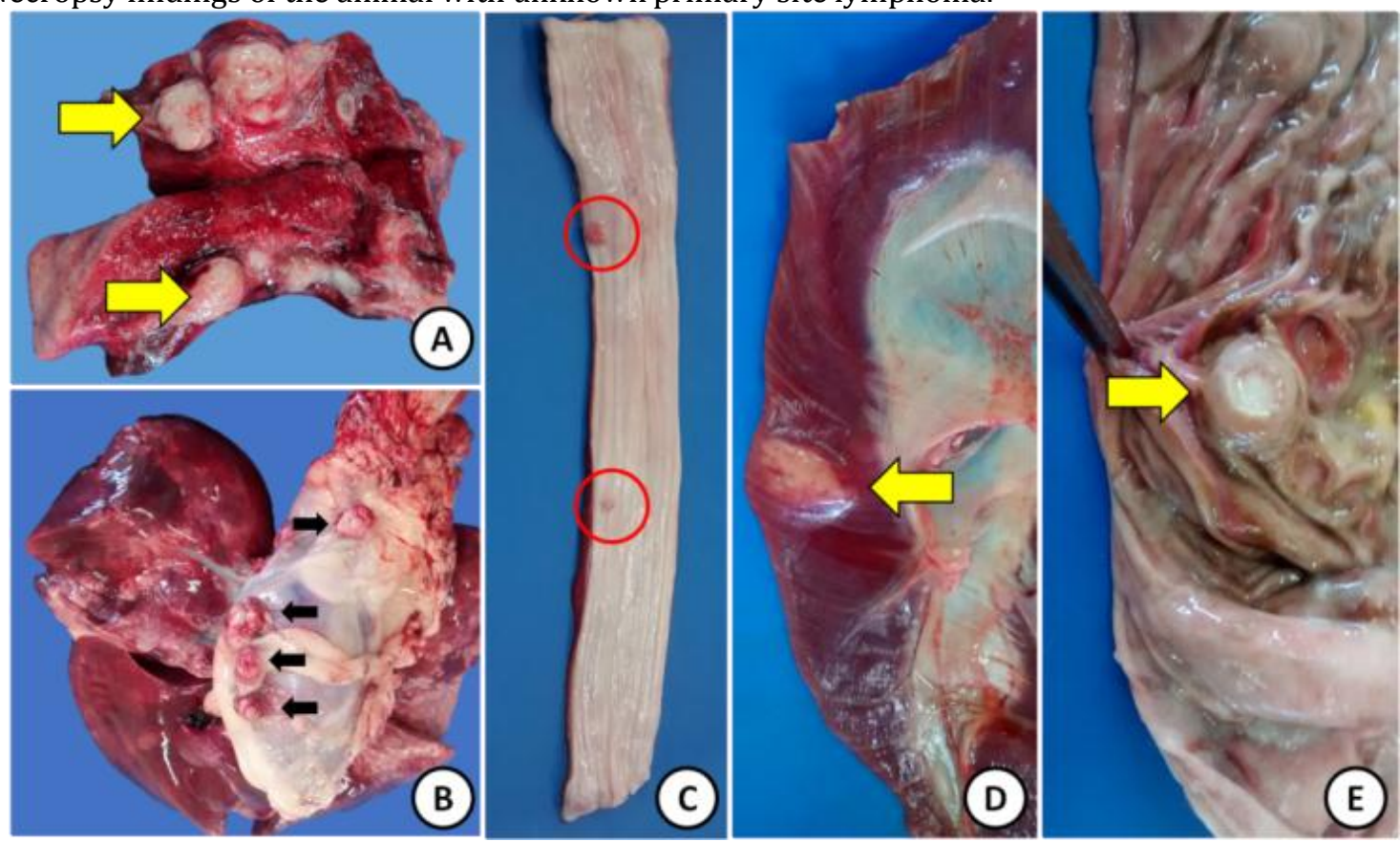

A: neoplasms $(3.0 \times 3.0 \mathrm{~cm})$ in the cut surface of the right caudal lobe of the lung (yellow arrows). B: neoplasms $(2.0 \times 2.0$ $\mathrm{cm}$ ) In the parietal lamina of the pericardium (black arrows).C: neoplasms $(1.0 \mathrm{x} 1.0 \mathrm{~cm})$ in esophageal mucosa (red circles). D: neoplasm $(3.0 \times 3.0 \mathrm{~cm})$ in diaphragmatic muscles (yellow arrow).E: Neoplastic mass $(3.0 \times 3.0 \mathrm{~cm}) \mathrm{ulcerated}$ in gastric mucosa (yellow arrow). Source: Personal archive.

Figure 5 - Photomicrography of histopathological and immunohistochemical examination of canine lymphoma of unknown primary site.

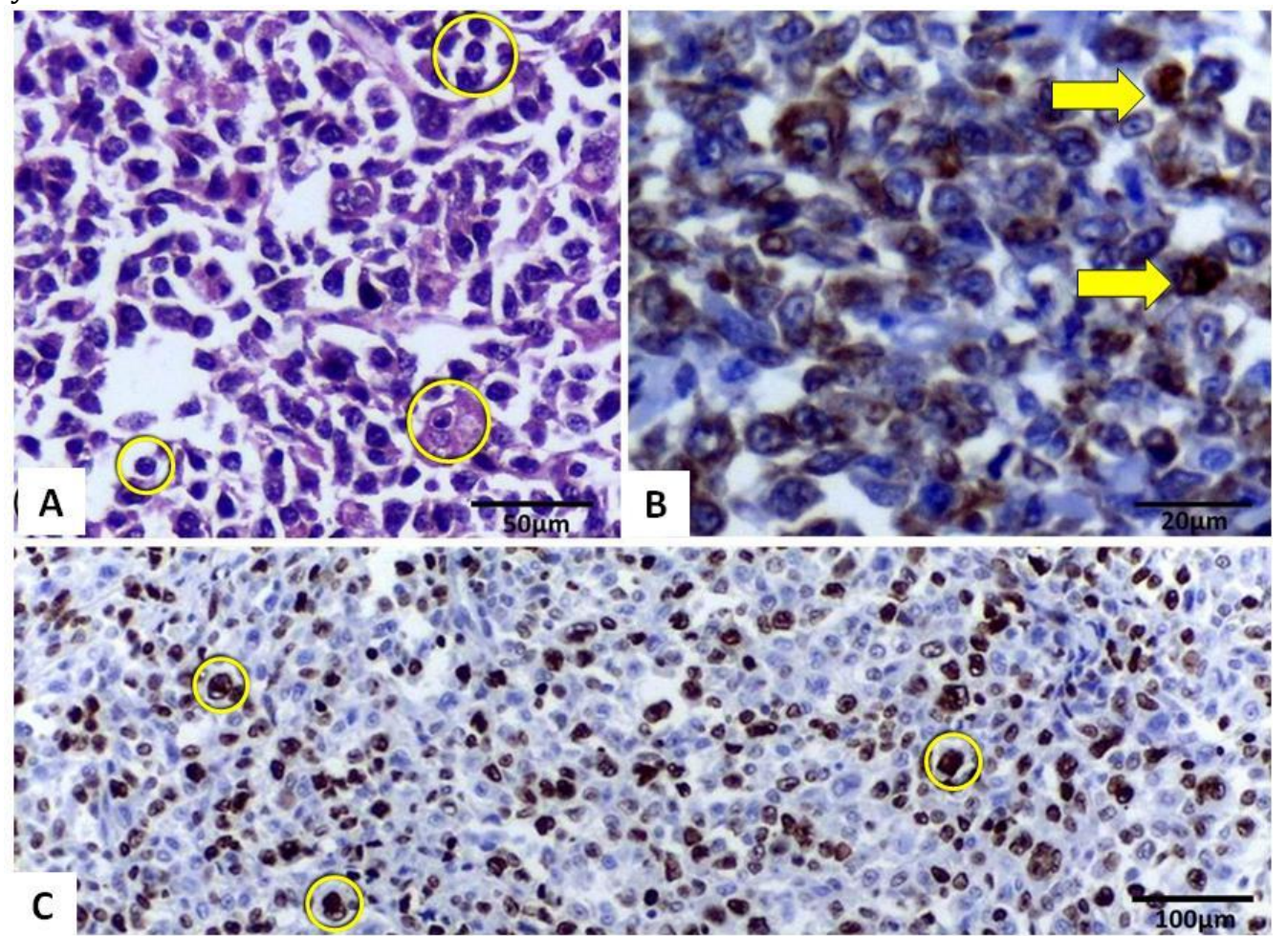

A: Proliferation presenting neoplastic round cells (yellow circles), with lymphocyte characteristics, presenting anisokaryosis, nuclear atypia and evident nucleoli (40x objective, staining: Hematoxylin and Eosin). B: Immunohistochemical panel evidencing positive result for the T lymphocyte receptor - CD3 antibody (yellow arrows) (20x objective). C: Immunohistochemical panel evidencing a positive result for the cell proliferation antigen - Ki67 antibody (yellow circles) (20x objective). Source: Personal archive. 
Table 2. Immunohistochemical examination of samples of neoplasms (located in subcutaneous tissue, diaphragm, intermuscular spaces, lung, pericardium, esophagus, stomach and large intestine), peripheral lymph nodes, liver, and spleen, of a female dog with metastatic lymphoma of unknown origin.

\begin{tabular}{lcl}
\hline Antibody & Clone & \\
\hline CD3: Epsilon chain T lymphocyte receptor & CD3-12 & Positive in neoplastic cells \\
CD20: marker of lymphoid B line, persisting in some & Polyclonal & Negative in neoplastic cells \\
plasma cells & & \\
PAX5: B cell-specific activating protein & $24 /$ PAX-5 & Negative in neoplastic cells \\
Ki67: cell proliferation antigen & MIB-1 & $\begin{array}{l}\text { Nuclear positivity in approximately 70\% of } \\
\text { neoplastic cells }\end{array}$ \\
\hline
\end{tabular}

\section{DISCUSSION}

Neoplasms of hematopoietic origin represent approximately 8 to $9 \%$ of malignant canine proliferations, with lymphoma accounting for about $90 \%$ of hematopoietic neoplasms and $24 \%$ of all neoplasms in the species (RODRIGUES et al., 2016). Older animals, above seven years of age, constitute the most affected age group (NEUWALD et al., 2014; VILLAMIL et al., 2009). Dogs up to four years of age are less likely to develop the disease, demonstrating that the case reported occurred in an age group unusual for cancer (VILLAMIL et al., 2009).

The dog of the present report fit the breed pattern predisposed to the development of lymphoma, since, according to some studies, there is a greater prevalence for such neoplasm in Boxer, Golden Retriever, German Shepherd, Labrador Retriever, Poodle and Rottweiler dogs (NEUWALD et al., 2014; VILLAMIL et al., 2009).

The clinical manifestations exhibited by the animal under discussion showed similarity to those in the literature (NEUWALD et al., 2014); highlighting that in some canine hematopoietic neoplasm cases, lymphadenopathy, progressive weight loss, anorexia, local (or generalized) edema, and emesis are the only reported clinical signs. The cutaneous lesions evidenced in the animal in question are related to the cutaneous form of the lymphoma, which is characterized by the formation of plaques and/or multifocal or even generalized skin nodules (DUARTE et al., 2016). Neoplastic infiltration in the lower respiratory tract was also observed in the reported animal, generating a condition of chronic obstructive pulmonary disease (COPD), which is characterized by a chronic and continuous restriction of the gas flow to the airways, triggering the clinical signs (POSADA; MONKS; CASTRO, 2014), which justified the presence of cough and respiratory distress. Limb edema is highly evidenced in lymphomas, affecting mainly the pelvic limbs, due to obstruction to the lymphatic flow (CÁPUA et al., 2011; RIBEIRO; ALEIXO; ANDRADE, 2015). This characteristic was similar to the clinical manifestation of the bitch in question, and a probable lymphatic obstructive process occurred in the development of pelvic limb edema.
Weakness and altered appetite were possibly related, in part, to the algic process secondary to the neoplastic presence, considering that the neoplasms may promote pain at any evolutionary phase of its clinical course, although the progression of the oncopathy intensifies the painful process (BILLER et al., 2016). There were also different causes related to the eating disorder evidenced in the dog, which could be due to the local compressive action of the neoplasm, a relationship with paraneoplastic syndromes, or the generalization of the metastasis (BILLER et al., 2016; RIBEIRO; ALEIXO; ANDRADE, 2015).

Despite non-specific, changes in the blood count have aided in staging the disease, which had already been reported as common in patients with lymphoid neoplasms (RIBEIRO; ALEIXO; ANDRADE, 2015). This may occur owing to either direct tumor action on the lymphatic and hematopoietic organs or secondary effects on the paraneoplastic syndromes in lymphoma (CÁPUA et al., 2011).

Anemia was one of the major paraneoplastic syndromes associated with lymphoma, mainly due to the release of neoplastic erythropoiesis-depressing factors (OLIVEIRA et al., 2013). Thrombocytopenia was considered common by the literature reports and caused by the invasion of the spinal cord by the neoplasm, in addition to platelet consumption (ZANDLIET, 2016). Although some animals with lymphoma show lymphocytosis, lymphopenia can also be observed due to a decrease in normal lymphocyte maturation or lysis of this neoplastic cell type (RIBEIRO; ALEIXO; ANDRADE, 2015), which probably occurred with the dog of the present case report.

Serum biochemical examination of dogs with hematopoietic neoplasms is often abnormal (MORTIER et al., 2012; ZANDLIET, 2016). Hypocalcemia observed in the dog was not consistent with the literature (MIRRAKHIMOV, 2015), since the majority of individuals with lymphoma present an increase in the serum calcium concentration due to the release of osteoclast activating factors, leading to an increase in bone resorption. This alteration is believed to be secondary to the production of parathyroid hormone-related protein (PTH) by neoplastic cells (BERGMAN, 2012; MIRRAKHIMOV, 2015). Hypocalcaemia was related to 
the likely occurrence of hypomagnesemia, vitamin D deficiency, massive cell lysis, osteoblastic metastasis, or low levels of PTH (FAROLFI et al. 2015; OKAZAKI et al., 2017).

Both the fast evolution of clinical signs, which hindered the relationship between clinical pattern and neoplastic disease, and the simultaneous affection of several organ systems as shown in the necropsy, the lymphoma could not be classified anatomically as seen in the literature (RIBEIRO; ALEIXO; ANDRADE, 2015; RODRIGUES et al., 2016). Thus, determining the primary origin of the neoplasm was impossible, which justified considering the case in question as a CUP.

To the authors, the present report was a rare case of lymphoma whose origin could not be identified. Rossi et al. (2015) observed higher frequencies, in descending order, of non-determined neoplasms for carcinomas, sarcomas, melanomas, and mastocytomas but no cases of lymphoma. This information is corroborated by recent studies in human patients (GRECO et al., 2015), in which lymphoma was the less diagnosed neoplasm of unknown origin.

Proliferation and rapid spread occur due to the extremely aggressive behavior of the unknown primary neoplasm (HEMMINKI et al., 2012). In the present case, CUP diagnosis was recommended as some criteria had been verified, such as inconclusive clinical, hematological, and biochemical evaluations; primary location undetectable through complementary imaging tests; and histopathological findings incompatible with primary neoplasm, as suggested by several authors (BEVIER; SUNDQUIST; HEMMINKI, 2012; HEMMINKI et al., 2012; RIIHIMAKI et al., 2014).

The characterization of phenotypic markers by means of an immunohistochemical panel was important for the identification and classification of neoplastic cells in the present case since this test allows evaluating fundamental determinants regarding aggressiveness and therapeutic response, which are closely related to the biological behavior and, therefore, with prognostic value. (CÁPUA et al., 2011). Therefore, the identification of the cell type of the oncological disease as a T-cell lymphoma corroborated with the rapid clinical evolution and intense tumor dissemination exhibited in the dog in question, considering that T-cell lymphomas tend to be biologically more aggressive when compared to those of immunophenotype B (SILVA; SEQUEIRA, 2016).

Although the result of the immunohistochemical examination of the bitch of the present case defined the lymphoma as T-cell, in the literature the vast majority of canine lymphomas are described as being B-cells, representing $60-80 \%$ of the cases (PONCE et al., 2010; VEZZALI et al., 2010; RODRIGUES et al., 2016). Such reports may explain the good rates of clinical remission of lymphoma in most canine patients undergoing chemotherapy protocols, unlike the animal in the present report, in which the advanced stage of the disease resulted in an unfavorable outcome, without therapeutic perspectives, and the impossibility of determining the primary site of neoplasm.

\section{CONCLUSIONS}

Metastatic lymphoma with unidentified primary origin may show rapid evolution and unfavorable prognosis in dogs. Due to the difficult clinical diagnosis, it is necessary to use several complementary tests. A greater number of studies are necessary to understand more about CUP related to canine hematopoietic neoplasms.

\section{REFERENCES}

BERGMAN, P. J. Paraneoplastic Hypercalcemia. Topics in Companion Animal Medicine, v. 27, n. 1, p. 156-158, 2012.

BEVIER, M.; SUNDQUIST, J.; HEMMINKI, K. Incidence of cancer of unknown primary in Sweden: analysis by location of metastasis. European Journal of Cancer Prevention, v. 21, n. 6, p. 596-601, 2012.

BILLER, B. et al. 2016 AAHA Oncology Guidelines for Dogs and Cats. Journal of the American Animal Hospital Association, v. 52, n. 4, p. 181-204, 2016.

CÁPUA, M. L. B. et al. Linfoma canino: clínica, hematologia e tratamento com o protocolo de Madison-Wisconsin. Ciência Rural, v. 41, n. 7, p. 1245-51, 2011.

COSTA, M. P. et al. Bioquímica sérica de cães infectados por Ehrlichia canis, Anaplasma platys e Leishmania sp. Acta Scientiae Veterinariae, v. 43 , n. 1, p. 1-7, 2015.

DUARTE, A. R. et al. Clinical and laboratorial evaluation of dogs with cutaneous lymphoma treated with lomustine. Brazilian Journal of Veterinary Research and Animal Science, v. 53, n. 1, p. 39-47, 2016.

FAROLFI, A. et al. Paraneoplastic hypocalcemia-induced heart failure in advanced breast cancer: A case report and literature review. Oncology Letters, v. 10, n. 2, p. 773-777, 2015.

GRECO, F. A. et al. Poorly differentiated neoplasms of unknown primary site: diagnostic usefulness of a molecular cancer classifier assay. Molecular diagnosis \& therapy, v. 19, n. 2, p. 91-97, 2015.

HEMMINKI, K. et al. Cancer of unknown primary (CUP): does cause of death and family history implicate hidden phenotypically changed primaries? Annals of Oncology, v. 23, n. 10, p. 2720-2724, 2012.

MARCONATO, L.; GELAIN, M. E.; COMAZZI, S. The dog as a possible animal model for human non-Hodgkin lymphoma: a review. Hematological Oncology, v. 31, n. 1, p. 1-9, 2012.

MIRRAKHIMOV, A. E. Hypercalcemia of malignancy: an update on pathogenesis and management. North American Journal of Medical Sciences, v. 7, n. 11, p. 483-493, 2015.

MORTIER, F. et al. Canine lymphoma: a retrospective study (2009 2010). Vlaams Diergeneeskundig Tijdschrift, v. 81, n. 6, p. 341-351, 2012.

NEUWALD, E. B. et al. Epidemiological, clinical and immunohistochemical aspects of canine lymphoma in the region of Porto Alegre, Brazil. Pesquisa Veterinária Brasileira, v. 34, n. 4, p. 349-54, 2014. 
OKAZAKI, J. et al. Paraneoplastic hypocalcemia developed in gastric cancer accompanied by osteoblastic metastasis. Internal Medicine, v. 56, n. 11, p. 1345-1349, 2017.

OLIVEIRA, K. M. et al. Principais síndromes paraneoplásicas em cães e gatos. Enciclopédia Biosfera, v.9, n. 17, p. 2073-2088, 2013.

PONCE, F. et al. A morphological study of 608 cases of canine malignant lymphoma in France with a focus on comparative similarities between canine and human lymphoma morphology. Veterinary Pathology, v. 47 , n. 3, p. 414-3, 2010.

POSADA, W. A.; MONKS, J. F.; CASTRO, M. S. Doença pulmonar obstrutiva crônica: uma revisão sobre os efeitos da educação de pacientes. Revista de Ciências Farmacêuticas Básica e Aplicada, v. 35, n. 4, p. 533-538, 2014.

RIBEIRO, R. C. S.; ALEIXO, G. A. S; ANDRADE, L. S. S. Linfoma canino: revisão de literatura. Medicina Veterinária (UFRPE), v.9, n. 1-4, p. 10$19,2015$.

RIIHIMAKI M. et al. Causes of death in patients with extranodal cancer of unknown primary: searching for the primary site. BMC Cancer, v. 14 , n. 439 , p. $1-8,2014$.

RODRIGUES, R. T. G. A. et al. Linfoma intranasal em cão: aspectos clínicopatológicos e imunoistoquímicos. Acta Veterinaria Brasilica, v. 10 , n. 1 , p. $84-91,2016$.

ROSSI, F. et al. Metastatic cancer of unknown primary in 21 dogs. Veterinary and Comparative Oncology, v. 13, n. 1, p. 11-19, 2015.

SILVA, M. C. L.; SEQUEIRA, J. L. Linfoma canino: revisão de literatura com ênfase no linfoma difuso de grandes células B. Veterinária e Zootecnia, v. 23, n. 4, p. 571-576, 2016.

SONDERGAARD, D. et al. Prediction of primary tumors in cancers of unknown primary. Journal of Integrative Bioinformatics, v. 14, n. 2, p. 1-7, 2017.

TESSER, S. et al. Perfil hematológico de cães e gatos na cidade de Bento Gonçalves, Rio Grande do Sul. Arquivos de Ciências Veterinárias e Zoologia da UNIPAR, v. 19, n. 1, p. 47-51, 2016.

VEZZALI, E. et al. Histopathologic classification of 171 cases of canine and feline non Hodgkin lymphoma according to the WHO. Veterinary and Comparative Oncology, v. 8, n. 1, p. 38-49, 2010.

VILLAMIL, J. A. et al. Hormonal and sex impact on the epidemiology of canine lymphoma. Journal of Cancer Epidemiology, v. 1, n. 1, p. 1-7, 2009.

ZANDVLIET, M. Canine lymphoma: a review. Veterinary Quarterly, v. 36 , n. 2 , p. $76-204,2016$ 